\title{
PRINSIP DESAIN ARSITEKTUR BIOKLIMATIK PADA IKLIM TROPIS
}

\author{
Jarwa Prasetya Sih Handoko \\ Jurusan Arsitektur FTSP UII, Mahasiswa Program Doktor Arsitektur DTAP UGM \\ jarwa.prasetya.s@mail.ugm.ac.id
}

\author{
Ikaputra \\ Program Doktor Arsitektur DTAP UGM \\ ikaputra@ugm.ac.id
}

Naskah diajukan pada: 16 Agustus 2019

Naskah revisi akhir diterima pada: 31 Oktober 2019

\begin{abstract}
Abstrak
Pertumbuhan pembangunan gedung yang tidak mempertimbangkan faktor kondisi alam menyebabkan munculnya potensi penurunan kualitas lingkungan hidup yang diakibatkan oleh konsumsi energi pada bangunan yang mengakibatkan menipisnya sumber daya alam, selain itu dilatar belakangi terjadinya fenomena perubahan iklim global yang menumbuhkan bangunan boros energi dalam kenyamanan fisik bangunan. Hal ini menumbuhkan kesadaran akan pentingnya desain arsitektur berbasis kondisi alam setempat termasuk kondisi iklim setempat atau pemanfaatan potensi Bioklimatik. Arsitektur Bioklimatik adalah adalah suatu pendekatan desain yang mengarahkan arsitek untuk mendapatkan penyelesaian desain dengan mempertimbangkan hubungan antara bentuk arsitektur dengan lingkungan iklim daerah tersebut. Kajian ini membahas prinsip desain Arsitektur Bioklimatik pada iklim tropis. Dengan demikian diharapkan dapat disusun theoritical framework terkait prinsip desain arsitektur pada iklim tropis. Iklim Tropis merujuk pada terminologi letak geografis daerah di sekitar equator diantara Garis Tropic of Cancer dan Tropic of Capricorn. Metode yang digunakan pada kajian ini dengan menggunakan studi pustaka atau studi referensi. Dari kajian ini dapat disimpulkan bahwa Prinsip Desain Arsitektur Bioklimatik pada Iklim Tropis terdiri dari 2 (dua) tipe meliputi Prinsip desain untuk bangunan pada daerah Iklim Tropika Basah (Hot humid Climate) yang memiliki 2 musim dan Prinsip desain untuk bangunan pada daerah iklim Tropika kering (Hot Arid Climate) dengan 4 musim. Kedua prinsip desain ini dipengaruhi beberapa perbedaan kondisi iklim diantara kedua wilayah iklim ini. Kedua wilayah ini secara umum memiliki temperature udara tinggi, perbedaannya adalah perbedaan suhu diurnal diantara kedua wilayah iklim tersebut. Kondisi ini memerlukan respon yang berbeda khususnya pada desain selubung bangunan, dimana desain selubung bangunan mempengaruhi tingkat heat gain (perolehan panas) dan heat loss (pembuangan panas) bangunan tersebut dalam upaya menciptakan indoor thermal comfort pada bangunan.
\end{abstract}

Kata-kata Kunci: Prinsip Desain, Arsitektur Bioklimatik, Iklim Tropis.

\section{PRINCIPLES OF BIOCLIMATIC ARCHITECTURAL DESIGN IN THE TROPICAL CLIMATE}

\begin{abstract}
The growth of building construction that does not consider natural conditions causes the potential for environmental degradation due to energy consumption in buildings, which and results in the depletion of natural resource. In addition to the occurrence of global climate change
\end{abstract}


phenomena that foster energy-intensive for buildings to fulfill the physical comfort. This condition raises awareness of the importance of architectural design based on local natural conditions including local climatic conditions or the utilization of bioclimatic potential. Bioclimatic Architecture is a design approach that directs architects to get a design finish by considering the relationship between architectural forms and the climate environment of the area. This study discusses the principles of Bioclimatic Architecture design in tropical climates. Thus the theoretical framework is expected to be arranged related to the principles of architectural design in tropical climates. Tropical climate refers to the terminology of the geographical location of the area around the equator between the Tropic of Cancer and Tropic of Capricorn Lines. The method used in this study is a literature study or reference study. From this study it can be concluded that the principles of Bioclimatic Architectural Design in Tropical Climates consist of 2 (two) types, including design principles for buildings in the Hot Humid Climate area which has 2 seasons and design principles for buildings in dry tropical climate regions (Hot Arid Climate) with 4 seasons. These two design principles are influenced by several different climatic conditions between these two climatic regions. These two regions generally have high air temperatures; the difference is the diurnal temperature difference between the two climate regions. This condition requires a different response, especially in the design of the building envelope, where the design of the building envelope influences the level of heat gain and heat loss in the effort to create indoor thermal comfort in the building.

Keywords: Design Principles, Bioclimatic Architecture, Tropical Climate

\section{Pendahuluan}

Terjadinya fenomena perubahan iklim global dan juga menurunnya kualitas lingkungan hidup yang diakibatkan oleh pertumbuhan dan percepatan industrialisme dan konsumsi energi yang mengakibatkan menipisnya sumber daya alam menumbuhkan kesadaran akan pentingnya design arsitektur berbasis kondisi iklim setempat. (Krishan et. al, 2001). Hal ini juga disampaikan oleh Roaf (2003) dalam Hyde (2008) bahwa terdapat 4 (empat) latar belakang pentingnya pemanfaatan desain Bioklimatik: (1) Tingkat perubahan dalam tingkat variabilitas iklim dan modifikasi meningkat, membutuhkan adaptasi manusia dengan kondisi iklim dunia; (2) Cara mendasar untuk adaptasi dalam lingkungan binaan ini adalah penerapan metode yang lebih efektif untuk bangunan yaitu pendingin pasif; (3) Sistem pengkondisian udara semakin dipandang sebagai bagian dari masalah perubahan iklim, tidak seimbangnya antara jumlah bahan bakar fosil yang digunakan di dunia dan jumlah bahan bakar fosil yang semakin berkurang yang tersedia; (4) Sangat penting untuk membuat pendekatan pembangunan 'vernakular' yang baru, yang sesuai dengan kebutuhan manusia dan lingkungan.

Masalah bioklimatik dalam bangunan diidentifikasi pertama kali oleh Olgyay pada tahun 1950an dan dikembangkan sebagai proses desain pada tahun 1960-an. (Olgyay, 1963). Proses desain menyatukan disiplin ilmu fisiologi manusia, klimatologi dan fisika bangunan. (Szokolay, 2004) dan selama beberapa tahun terakhir telah dipandang sebagai landasan untuk mencapai bangunan yang lebih berkelanjutan. (Szokolay, 2004; Hyde, 2008). Prinsip-prinsip bioklimatik, strategi dan solusi praktik terbaik untuk bangunan masih harus diteliti dan diakui sepenuhnya di dalam bidang ini. ( Yeang, 1999 dalam Hyde, 2008).

Daerah iklim tropis meliputi wilayah dekat dengan ekuator diantara garis balik Tropic of cancer dan Tropic of Capicorn. Daerah ini meliputi wilayah $40 \%$ seluruh wilayah dunia yang memiliki potensi dan karakteristik yang jauh melampaui yang ditemukan di iklim yang lebih sejuk. (Hyde, 2000). Oleh karena itu perlu dilakukan suatu kajian mengenai prinsip desain Arsitektur Bioklimatik pada daerah iklim tropis. 
Oleh karena itu, dari uraian fenomena diatas perlu dilakukan suatu kajian yang mengeksplorasi prinsip desain arsitektur bioklimatik khususnya di Iklim Tropis. Dari kajian ini diharapkan dapat disusun theoritical framework terkait prinsip desain arsitektur pada iklim tropis bersumber pada studi pustaka yang dilakukan.

\section{Kajian Pustaka Arsitektur dan Iklim}

Hubungan antara iklim indoor dan outdoor sangat tergantung pada desain arsitektur dan struktur bangunan, selanjutnya iklim dalam ruangan dapat dikendalikan oleh desain bangunan untuk mengakomodasi kebutuhan kenyamanan manusia (Givoni, 1998). Sejalan dengan hal tersebut Kukreja (1978) menyatakan bahwa Iklim memiliki pengaruh yang dominan terhadap arsitektur di seluruh dunia dan disemua periode waktu.

Menurut Olgyay (1963) terdapat empat bidang yang saling mempengaruhi dalam desain arsitektur terkait iklim yaitu klimatologi, biologi, teknologi dan arsitektur. Langkah pertama mewujudkan arsitektur tanggap iklim adalah survei elemen iklim yang ada di lokasi tertentu, hal ini karena manusia adalah faktor utama dalam arsitektur dan tempat tinggal dirancang untuk memenuhi kebutuhan biologis manusia. Langkah berikutnya adalah mengevaluasi dampak setiap elemen iklim terhadap fisiologis manusia. Sebagai langkah ketiga penerapan solusi teknologi dalam mengatasi persoalan kenyamanan bangunan terkait kondisi iklim, dan ditahap akhir solusi harus dikombinasikan sesuai dengan kepentingan pengguna dalam kesatuan arsitektur (Olgyay, 1963).

Penerapan solusi teknologi menurut Olgyay terdapat enam faktor penentu yaitu: pemilihan lokasi, orientasi matahari, perhitungan shading, bentuk rumah dan bentuk bangunan, gerakan udara (Angin dan ventilasi) dan suhu ruangan. Semua faktor tersebut berkontribusi untuk mewujudkan $a$ balanced shelter (Olgyay, 1963).

Menurut Givoni (1998) terdapat beberapa fitur desain arsitektur dari desain bangunan yang mempengaruhi iklim dalam ruangan. Fitur tersebut melakukan ini dengan memodifikasi empat bentuk interaksi antara bangunan dan lingkungannya :

1. Paparan sinar matahari yang efektif (effective solar exposure) dari elemen berlapis kaca dan buram envelope bangunan (dinding dan atapnya)

2. Perolehan panas matahari efektif (effective solar heat gain) bangunan

3. Tingkat perolehan panas konduktif dan konvektif (conductive and convective) dari udara sekitar.

4. Potensi ventilasi alami dan pendinginan pasif bangunan

\section{Arsitektur Bioklimatik}

Istilah "Bioklimatik" secara tradisional terkait dengan hubungan antara iklim dan organisme hidup atau dengan studi bioklimatologi atau menekankan bidang biologi, klimatologi atau menekankan bidang biologi, klimatologi dan arsitektur secara bersamaan (Hyde, 2008; Olgyay, 1963). Dalam konteks bangunan secara umum dan rumah secara khusus berkaitan dengan hubungan antara 3 (tiga) faktor yaitu antara organisme hidup, iklim dan bentuk dan bahan bangunan. ( Hyde, 2008).

Selanjutnya desain perumahan sesuai dengan prinsip-prinsip bioklimatik menjadi bagian penting dari perjalanan menuju pencapaian pembangunan ekologis yang berkelanjutan. Keberlanjutan dipandang sebagai hasil, bukan sebagai tujuan atau proses. Ini dapat dikonseptualisasikan sebagai desain bangunan yang memanfaatkan berbagai elemen biofisik. Unsur biofisik ini terutama diambil dari ekosfer, bukan litosfer, yaitu panas, cahaya, landscape, udara, hujan, dan material ( Hyde, 2008).

Sedangkan menurut Kenneth Yeang "Bioclimatology is the study of the relationship between climate and life, particulary the effect of climate on the health of activity of living things". 
Bioklimatik adalah Ilmu yang mempelajari antara hubungan iklim dan kehidupan terutama efek dari iklim pada kesehatan dan aktivitas sehari-hari. Ken Yeang (1994) mengemukakan beberapa alasan kuat yang mengharuskan penerapan bioklimatik dalam desain, yakni : pemanfaatan energi yang lebih rendah dalam pengoperasian bangunan, keinginan untuk merasakan iklim eksternal yang khas dari suatu tempat dan kepedulian terhadap lingkungan ekologis. (Ken Yeang, 1994.) sejalan dengan hal tersebut Almusaed (2011) menyatakan bahwa Arsitektur Bioklimatik menggabungkan kepentingan keberlanjutan, kesadaran lingkungan hijau, alami, organik dan merespon karakteristik lahan, konteks lingkungannya, iklim mikro setempat dan topografinya.

Arsitektur Bioklimatik berkaitan dengan iklim atau persepsi iklim sebagai generator kontekstual utama desain dengan menggunakan energi minimal untuk menciptakan kenyamanan termal di dalam ruangan. Bangunan Bioklimatik adalah merupakan hasil adaptasi terhadap iklim dan lingkungan sekitarnya, (Almusaed, 2011) bangunan yang berinteraksi dengan lingkungan dengan penjelmaan dan operasinya serta penampilan berkualitas tinggi. (Yeang, 1996). Arsitektur tanggap Iklim adalah konsep arsitektur yang menekankan pada potensi bangunan sebagai filter antara lingkungan indoor dan outdoor (Hasting, 1989). Fungsi filter bangunan ini dianggap sebagai aspek utama dalam mewujudkan bangunan yang nyaman, bersama dengan upaya manusia dalam pengendalian iklim untuk memenuhi kebutuhan subjektif pengguna bangunan (Fountain et All,1996, Mahdavi dan Kumar, 1996).

Terdapat banyak penelitian yang terkait arsitektur bioklimatik. Prianto et al. (2018) dalam penelitiannya menyampaikan bahwa semakin tangguh suatu desain arsitektur adalah keseimbangan antara pengentasan dan pendayagunaan faktor iklim yang diadaptasi dalam desain bangunannya. Selain itu sejalan dengan apa yang disampaikan oleh Karyono (2006) bahwa desain arsitektur yang mengadaptasi kondisi iklim luar terkait dengan pemenuhan kenyamanan fisik bangunan. Kenyamanan termal menjadi salah satu kenyamanan fisik bangunan yang paling banyak berhubungan dengan hampir semua faktor iklim. Terdapat banyak cara yang dilakukan manusia dalam memodifikasi iklim luar yang tidak nyaman menjadi kondisi nyaman pada bangunan. Terdapat metode mekanis dan metode pemanfaatan energi matahari. Metode pemanfaatan energi matahari ini mempertimbangkan fakta bahwa semua faktor iklim berasal dari matahari sehingga dengan memanfaatkan energi matahari dapat menciptakan kenyamanan fisik bangunan tanpa menggunakan banyak energi tambahan. Mengenai efektifitas penggunaan energi dengan penerapan arsitektur Bioklimatik juga disampaikan bahwa bangunan yang mempertimbangkan kondisi bioklimatik lingkungan tidak memerlukan tambahan biaya pembangunan dan memiliki dampak lingkungan yang minimal. Arsitektur bioklimatik menciptakan peluang besar bagi negara berkembang untuk pembangunannya. Dengan semakin banyaknya bangunan menggunakan konsep bioklimatik maka akan lebih banyak penghematan energi dalam operasional bangunan. (Tumimomor et al., 2011; Widera, 2014).

Terdapat beberapa contoh bangunan karya Arsitek Ken Yeang yang menerapkan konsep arsitektur bioklimatik diantaranya Menara Mesiniaga, Plaza Atrium dengan penerapan vertikal landscape. Selain itu Solaris Fusionopolis dan the High-rise National Library Board Building di Singapura dengan adanya shaft matahari, ventilasi alami dan atrium besar yang menangkap sinar matahari, termasuk fasade bangunan yang digunakan sebagai penangkap air hujan (https://archnet.org/authorities/380/sites/802, 2019).

Jadi arsitektur bioklimatik adalah suatu pendekatan yang mengarahkan arsitek untuk mendapatkan penyelesaian desain dengan memperhatikan hubungan antara bentuk arsitektur dengan lingkungannya iklim daerah tersebut. Pada akhirnya bentuk arsitektur yang dihasilkan dipengaruhi oleh budaya setempat, dan hal ini akan berpengaruh pada arsitektur yang akan ditampilkan dari suatu bangunan, selain itu pendekatan bioklimatik akan mengurangi ketergantungan karya arsitektur terhadap sumber energi yang tidak dapat dipengaruhi. (Yeang, 1996). 


\section{Kenyamanan Bangunan}

Ada tiga sasaran yang seharusnya dipenuhi oleh suatu karya arsitektur. Pertama, bahwa bangunan harus mampu memberikan kenyamanan (baik psikis maupun fisik) kepada penghuninya. (Karyono, 1996) Terdapat dua aspek kenyamanan yang perlu dipenuhi oleh suatu karya arsitektur, yakni :

1. Kenyamanan Psikis

Kenyamanan psikis banyak kaitannya dengan kepercayaan, agama, aturan adat dan sebagainya. Aspek ini bersifat personal, kualitatif dan tidak terukur secara kuantitatif.

2. Kenyamanan Fisik

Sedangkan kenyamanan fisik lebih bersifat universal dan dapat dikuantifikasikan. Terdiri dari : kenyamanan ruang (spatial comfort), kenyamanan penglihatan (visual comfort, kenyamanan pendengaran (audial comfort) dan kenyamanan suhu (thermal comfort) ( Karyono, 1989)

Hal ini sejalan dengan output dari arsitektur bioklimatik yaitu peningkatan kinerja dari: (1) kenyamanan dan kesejahteraan penghuni, definisi kenyamanan biofisik telah diperluas untuk mencakup berbagai masalah yang berkaitan dengan faktor sosial dan ekonomi; (2) Siklus hidup bangunan dan infrastruktur, ini termasuk pengurangan dampak lingkungan selama siklus hidup bangunan dan pengurangan seluruh biaya hidup bangunan. (Hyde, 2008)

\section{Metode}

Metode yang digunakan pada kajian ini adalah studi pustaka atau literatur. Tujuan dari kajian ini membahas prinsip desain Arsitektur Bioklimatik pada iklim tropis. Dari pendapat beberapa ahli akan disimpulkan terkait prinsip desain arsitektur pada iklim tropis. Studi pustaka diperoleh dari berbagai sumber yang diterbitkan seperti artikel jurnal, makalah, dan materi terkait lainnya. Pembahasan kajian ini dimulai dengan ulasan tentang zona iklim dan karakteristiknya selanjutnya dikaji pendapat beberapa ahli terkait arsitektur bioklimatik. Dengan penelitian ini, diharapkan dapat disusun theoritical framework terkait prinsip desain arsitektur pada iklim tropis.

\section{Hasil dan Pembahasan}

\section{Zona Iklim Tropis Dan Karakteristiknya}

Daerah tropis adalah daerah antara garis balik Cancer ( Tropic of Cancer ) di utara khatulistiwa pada $23^{\circ} 27^{\prime}$ LU dan garis balik Capricorn (Tropic of Capricorn) di selatan khatulistiwa pada 2327" LS. Pembagian bumi dengan garis-garis tegak ini tidak mempertimbangkan batas-batas darah iklim yang sebenarnya ( Lippsmeier, 1980). Iklim dibedakan menurut iklim makro dan mikro Iklim makro adalah keseluruhan kejadian meteorologis khusus di atmosfer. Iklim makro juga dipengaruhi oleh konsisi-kondisi topografis bumi dan perubahan-perubahan peradaban di permukaannya. Iklim makro berhubungan dengan ruang yang besar seperti negara, benua dan lautan. Iklim mikro berhubungan dengan ruang terbatas, yaitu ruang dalam, jalan, kota atau taman kecil. Kondisi iklim mikro ini meliputi data tentang temperature udara maksimum dan minimum, tingkat kelembaban maksimum dan minimum, jumlah hari hujan beserta curah hujan $(\mathrm{mm})$, lama penyinaran (sunshine duration), kecepatan angin dan kecenderungan arah angin dan besarnya radiasi matahari (Lippsmeier, 1980; Mangunwijaya, 2000).

Klasifikasi iklim Koppen dikembangkan oleh ahli iklim Wladimir Koppen. Sistem tersebut kemudian dikenal sebagai Koppen Geiger berdasarkan peta vegetasi Condolles tahun 1806 dengan peta curah hujan dan rata-rata suhu bulanan, yaitu hujan tropis, kering, hangat, sedang, dingin salju es, dan kutub. Sedangkan Olgyay (1963) membagi empat zona berdasarkan sistem Koppen yaitu : lembab panas, kering panas, daerah beriklim sedang dan dingin.

Menurut Oliver (1997) zona bumi dibagi menjadi 9 (sembilan) keragaman iklim berdasarkan dampak pada arsitektur yaitu Artic dan Sub Artic, Kontonental, Gurun, Maritim, Mediterania, Monsoon, Montane, Subtropis dan Tropis. Menurut Szokolay (1980) terdapat karakter empat musim 
utama yaitu Iklim Dingin (Cold Climate), Iklim Sedang (Temperate Climate), Iklim Panas Kering (Hot-Dry/Arid Climates), Iklim Panas Lembab (Warm-Humid Climates).

Zona tropis merupakan terminologi pembagian geografis yang merujuk pada wilayah yang terletak dekat katulistiwa Daerah iklim tropis terletak di antara $2312^{\circ}$ LS dan $231 / 2^{\circ}$ LU dan hampir $40 \%$ dari permukaan bumi yang mendapatkan sinar matahari secara vertikal pada siang hari. Yang dibatasi oleh garis The topic of Capricorn dan The Tropic of Cancer. Dari pembagian diatas zona tropis dibagi menjadi 2 daerah iklim, yaitu (1) daerah hangat lembab/ Tropika basah (Hot/Warm Humid Climate Zones) kurang lebih terletak antara $15^{\circ}$ LU dan $15^{\circ}$ LS. (2) Daerah Panas-Kering/ Tropika kering ( Hot-Dry/Arid Climate Zones) terletak antara $15^{\circ} \mathrm{LU}-30^{\circ} \mathrm{LU}$ dan $15^{\circ} \mathrm{LU}-30^{\circ} \mathrm{LS}$. Daerah hangat-Lembab (Hot/Warm- Humid Zones) ditandai dengan kondisi kelembaban tinggi $(>90 \%)$ curah hujan tinggi, serta temperatur rata-rata tahunan diatas $18^{\circ} \mathrm{C}$. Perbedaan musim hampir tidak ada dan fluktuasi temperatur tahunan sangat kecil. Oleh karena itu, pada daerah hangat-lembab, pengamatan ditekankan pada fluktuasi iklim harian. Pada daerah warm-humid Climate dibedakan atas dua daerah sekunder, yaitu (a) daerah hutan hujan tropis dan (b) daerah musim dan savana lembab. Indonesia yeng terletak diantara garis lintang $6^{\circ} 8^{\prime}$ LU dan $11^{\circ} 15^{\prime}$ LS termasuk dalam klasifikasi iklim tropika basah ( warm-humid climate) dengan iklim sekunder daerah hutan hujan tropis (tropical rain forest) (Lippsmeier, 1980; Koenigsberger et all., 1973; Kukreja, 1978).

Klasifikasi kedua Tropical Climate adalah Iklim Panas-Kering (Hot-Dry Climate), ditandai dengan kondisi kelembaban absolut $<25>50^{\circ} \mathrm{C}$, disertai dengan radiasi matahari yang tinggi. Perbedaan musim panas dan musim dingin sangat besar, hujan sedikit dengan perbedaan temperature siang-malam dalam musim dingin mencapai $>20^{\circ}$. Daerah iklim Tropika kering terdiri dari iklim sekunder: (1) daerah padang pasir dan setengah gurun dam (2) Daerah savana Kering. (Lippsmeier, 1980; Koenigsberger et all., 1973).

GA Atkinson (1953) dalam Koenigsberger et all. (1973) membagi iklim berdasarkan 2 (dua) faktor atmosfer utama yang paling mmepengaruhi kenyamanan manusia yaitu temperatur udara dan kelembaban. Berdasarkan hal ini maka dibagi menjadi tiga zona utama iklim yaitu warm humid equatorial climate atau warm humid climate, Hot dry desert climate dan Composite atau Monsoon Climate yang merupakan perpaduan antara Warm Humid Climate dan Hot dry desert climate. Pada zona Monsoon climate mengalami dua musim dalam satu tahun, dengan dua pertiga tahun mengalami kondisi iklim serupa dengan zona Hot-Dry Climate dan sepertiga tahun mengalami kondisi iklim serupa dengan zona Warm Humid Climate. ( Koenigsberger et all., 1973)

\section{Prinsip Umum Desain Bioklimatik}

Dalam pembahasan Arsitektur Bioklimatik, Matahari sebagai sumber energi utama yang mempengaruhi kondisi iklim. Hal ini terutama terkait dengan jumlah radiasi matahari yang diterima di suatu lokasi di bumi. Radiasi matahari adalah penyebab semua ciri umum iklim dan radiasi matahari sangat berpengaruh terhadap kehidupan manusia. Kekuatan efektifnya ditentukan oleh energi radiasi (insolasi) matahari, pemantulan pada permukaan bumi, berkurangnya radiasi oleh penguapan, dan arus radiasi di atmosfer ( Lippsmeier, 1980) dan merupakan pancaran energi yang berasal dari proses thermonuklir yang terjadi di Matahari. Energi radiasi Matahari berbentuk sinar dan gelombang elektromagnetik.

Jumlah radiasi matahari yang diterima di bumi tergantung beberapa faktor : (1) jarak matahari, setiap perubahan jarak bumi dan matahari menimbulkan variasi terhadap penerimaan energi matahari; (2) Intensitas radiasi matahari, yaitu besar kecilnya sudut datang sinar matahari pada permukaan bumi. Jumlah yang diterima berbanding lurus dengan sudut besarnya sudut datang. Sinar dengan sudut datang yang miring kurang memberikan energi pada permukaan bumi disebabkan karena energinya tersebar pada permukaan yang luas dan juga karena sinar tersebut harus menempuh lapisan atmosfer yang lebih jauh ketimbang jika sinar dengan sudut datang yang tegak lurus; (3) Panjang hari (sun duration), yaitu jarak dan lamanya antara Matahari terbit dan Matahari terbenam; 
(4) Pengaruh atmosfer. (Lippsmeier, 1980) dan (5) Sudut jatuh, yang ditentukan oleh posisi relatif matahari dan tempat pengamatan di bumi serta tergantung pada sudut lintang geografis tempat pengamatan, musim dan lama penyinaran harian matahari. ( Lippsmeier, 1980). Hal ini terlihat pada Gambar 1.

Selain tergantung pada jumlah radiasi matahari, kondisi iklim setempat juga dipengaruhi oleh topografi, vegetasi, kondisi bentang alam dan aspek detail site. (Szokolay, 1980; Koenigsberger et all., 1973; Evan, 1980). Kondisi iklim suatu site (lokasi) meliputi temperature harian, intensitas radiasi matahari, kelembaban, kecepatan angin (Aronin, 1953; Evan, 1980; Lippsmeier, 1980), debu (Lippsmeier, 1980). Perancangan bangunan harus memperhitungkan kondisi iklim yang ekstrem dari masing-masing region yang menjadi permasalahan utama bangunan pada region tersebut (Lippsmeier,1980).

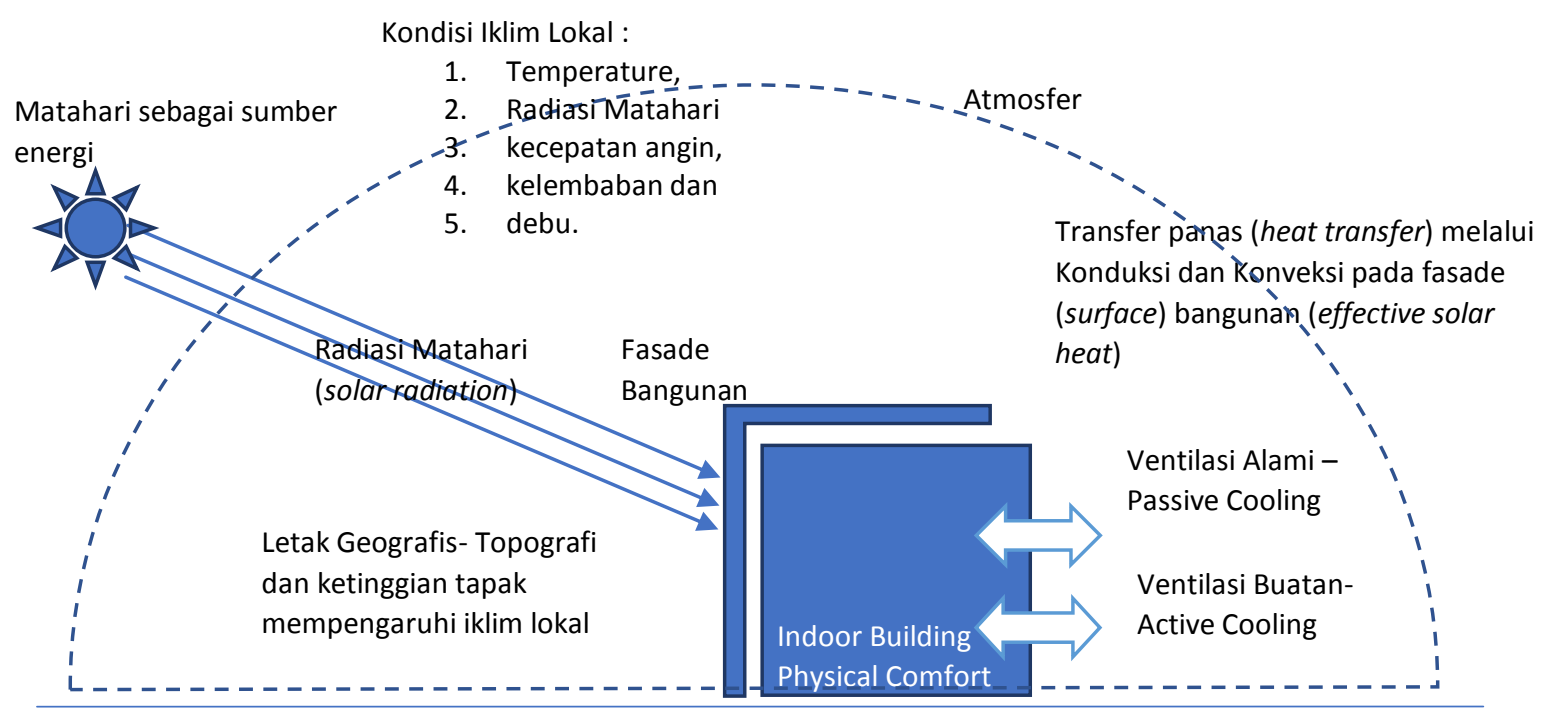

Gambar 1. Prinsip Umum Desain Arsitektur Bioklimatik

Sumber : Disarikan dari Lippsmeier, 1980; Szokolay, 1980; Koenigsberger et all., 1973; Evan, 1980; Aronin, 1953; Givoni, 1998.

Perancangan bangunan dalam merespon kondisi iklim tersebut diatas dengan melakukan kontrol terhadap interaksi antara bangunan dan kondisi iklim meliputi : (1) intensitas radiasi matahari yang efektif (effective solar exposure) pada building envelope sesuai dengan kemiringan sudut datang sinar matahari pada bangunan (Givoni, 1998; Evan,1980; Aronin, 1953), (2) perolehan panas matahari efektif (effective solar heat gain) bangunan, (3) tingkat perolehan panas konduktif dan konvektif ( conductive and convective) dari udara sekitar, (4) potensi bangunan memperoleh ventilasi alami dan pendinginan pasif bangunan (Givoni, 1998; Evan, 1980).

Fitur desain arsitektur yang berpengaruh pada interaksi antara bangunan dan lingkungannya adalah layout dan bentuk bangunan, orientasi jendela dan kondisi shading jendela, orientasi dan warna dinding, ukuran dan lokasi jendela terhadap aspek ventilasi, ventilasi pada bangunan, pemilihan material bangunan dan site landscaping. (Givoni, 1998).

Tabel 1. Prinsip Desain Arsitektur Bioklimatik

\begin{tabular}{lll}
\hline Sumber Referensi & & Prinsip Desain Arsitektur Bioklimatik \\
\hline & 1. & Summer \\
Watson (1983) & a. & Resist Heat Gain (menurunkan perolehan panas) \\
& & $\bullet \quad$ Minimize Conductive Heatflow \\
\hline
\end{tabular}




\begin{tabular}{|c|c|}
\hline & $\begin{array}{l}\text { - Minimize Infiltration } \\
\text { - Minimize Solar Gain } \\
\text { b. Promote Heat Loss (menaikkan perolehan panas) } \\
\text { - Promote Earth Cooling } \\
\text { - Promote Ventilation } \\
\text { - Promote Radiant Cooling } \\
\text { - Promote Evaporative Cooling } \\
\text { 2. Winter } \\
\text { a.Promote Heat Gain } \\
\text { - Promote Solar Gain } \\
\text { b. Resist Heat Gain } \\
\text { - Minimize Conductive Heat Flow } \\
\text { - Minimize External Air Flow } \\
\text { - Minimize Infiltration }\end{array}$ \\
\hline Givoni (1998) & $\begin{array}{l}\text { For Hot Dry Regions : } \\
\text { 1. Lowering the indoor temperatures } \\
\text { 2. Natural Vebtilation } \\
\text { 3. Minimizing heat gain and loss when air conditioning is unavoidable } \\
\text { 4. Utilization of natural energies for heating and cooling. } \\
\text { For Hot Humid Regions : } \\
\text { 1. Minimizing solar heating of the buildings } \\
\text { 2. Maximizing the rate of cooling in the evenings } \\
\text { 3. Providing effective natural ventilation, even during rain. } \\
\text { 4. Preventing rain penetration, even during rain } \\
\text { 5. Preventing entry of insects while the windows are open for ventilation. } \\
\text { 6. Providing spaces for semi outdoor activities as integral part of the living space. } \\
\text { 7. Minimize the risks from tropical storms. ( in region subjected to hurricanes or } \\
\text { typhoons) }\end{array}$ \\
\hline Yeang (1994) & $\begin{array}{l}\text { 1. Penempatan Core bukan hanya sebagai bagian struktur tapi juga mempengaruhi } \\
\text { kenyamanan termal. } \\
\text { 2. Menentukan Orientasi bangunan untuk menciptakan konservasi energi. } \\
\text { 3. Penempatan bukaan jendela mempertimbangkan fungsi ventilasi, perlindungan tata surya, } \\
\text { penerangan alami, area visualisasi dan kebebasan pribadi serta sistem luar yang aktif. } \\
\text { Cross ventilasi digunakan meningkatkan udara segar dan mengalirkan udara panas keluar. } \\
\text { 4. Penggunaan balkon sebagai pembayang sinar matahari. } \\
\text { 5. Membuat ruang transisional di tengah dan disekeliling bangunan sebagai ruang udara dan } \\
\text { atrium. } \\
\text { 6. Desain pada dinding, peggunaan membran yang menghubungkan bangunan dengan } \\
\text { lingkungan. } \\
\text { 7. Hubungan terhadap Lansekap, lantai dasar bangunan tropis seharusnya lebih terbuka dan } \\
\text { menggunakan ventilasi alami. } \\
\text { 8. Menggunakan alat pembayang pasif sebagai esensi pembiasan sinar matahari pada } \\
\text { dinding yang menghadap matahari langsung. } \\
\text { 9. Penyekat panas pada lantai, insolator panas yang baik pada kulit bangunan dapat } \\
\text { mengurangi pertukaran panas yang terik dengan udara dingin yang berasal dari dalam } \\
\text { bangunan. }\end{array}$ \\
\hline Lippsmeier (1980) & $\begin{array}{l}\text { Perancangan harus memperhitungkan kondisi iklim yang ekstrem. Kontrol terhadap efek } \\
\text { radiasi matahari yang intensif, angin kering yang membawa debu, tingginya kelembaban, } \\
\text { besarnya temperature harian pada bangunan. } \\
\text { Tropika Basah : } \\
\text { 1. Penggunaan konstruksi ringan dan terbuka. } \\
\text { 2. Penggunaan peneduhan dan permukaan yang dapat memantulkan cahaya. } \\
\text { 3. Pembuatan ventilasi alamiah. } \\
\text { 4. Segala jenis penyerap panas harus dihindarkan dan bidang dinding dapat dibuka } \\
\text { 5. Pelebar mungkin untuk mendapatkan ventilasi silang yang diperlukan. } \\
\text { angin. }\end{array}$ \\
\hline
\end{tabular}




\section{Tropika kering :}

1. Penggunaan konstruksi berat dan tertutup

2. Pemakaian dinding dengan sedikit lobang/masif

Aronin (1953)

1. Control amount of radiation received from the sun.(sun radiation)

2. Respect to winds

\section{Hot Arid Region}

- High altitude and location with evaporative possibilities, cool air flow effect, are advantageous.

- A radiation absorbent surface and for its evaporative and shade giving properties is needed.

- $\quad$ High massive building are preferable.

- Heat Loss, rather than gain, is the objective.

- Avoid heat gain

- $\quad$ Shading devices exposed to wind convection.

Olgyay (1936)

\section{Hot Humid Region}

- Site selection and building should be shaded structures which encourage cooling air movements, shade protection should be on all sun exposed side.

- Interior spaces must be shaded and well ventilated.

- To avoid glare both inside and outside.

- Cross ventilation is essential.

- Stucture must be sheltered from sun and rain and hurricane.

- Foundation must be proctected from moisture, mold, fungus, termites.

- The structure must be protected againts fungus, mold and dampness effects. A flow of breze is necessary to compensate for this. Structures must be designed to withstand hurricane velocity winds.

1. Promotion Provide Space Cooling in Summer

Looman, R (2017) 2. Promotion Provide Space Heating in Winter

3. Prevention Heat Loss Limitation in Winter

1. Minimize heat loss in winter

2. Allow solar access in winter

3. Minimize heat loss in winter

4. Allow solar access in winter

1. Minimize heat loss in winter and heat gain in summer

Hyde (2000) 2. Utilize diurnal temperature variation for summer cooling, winter heating.

3. Provide dust barriers at openings

4. Utilize small amount of rain and low humidity

1. Minimize heat gain

2. Maximize ventilation

3. Maximize shading

\section{Hot dry Climate}

1. Reduce the external diurnal range effect.

2. Decreased internal temperature range.

\section{Warm Humid Climate}

Evan (1980)

1. Air movement is essential and internal surface temperatures should be kept as low as possible during the day and the night.

2. Reduce solar solar heat gain and avoid the storage of heat which would increase discomfort at night.

3. The reflectivity and the insulation of the material should be selected so that the internal ceiling temperature does not rise more than 4,5 deg $\mathrm{C}$.

4. The Solar heat factor for walls should also be selected to avoid excessive internal surface temperatures.

Sumber: Disarikan dari Watson (1983); Aronin (1953); Yeang (1994); Givoni (1998); Lippsmeier (1980); Olgyay (1963); Evan (1980); Looman (2017), Hyde (2000) 


\section{Prinsip Desain Bioklimatik Pada Daerah Tropika Basah (Warm- Humid Climate Region)}

Prinsip desain bioklimatik pada Warm-Humid Climate Region meliputi : (1) Meminimalkan pemanasan matahari (heat gain) pada bangunan (Yeang, 1994); (2) mencegah masuknya serangga ketika jendela terbuka untuk ventilasi; (3) meminimalkan risiko dari badai tropis, (4) menyediakan ventilasi alami yang efektif; (5) memaksimalkan laju pendinginan di malam hari; (6) mencegah penetrasi hujan (Givoni, 1998; Lippsmeier, 1980; Olgyay, 1963; Evan, 1980).

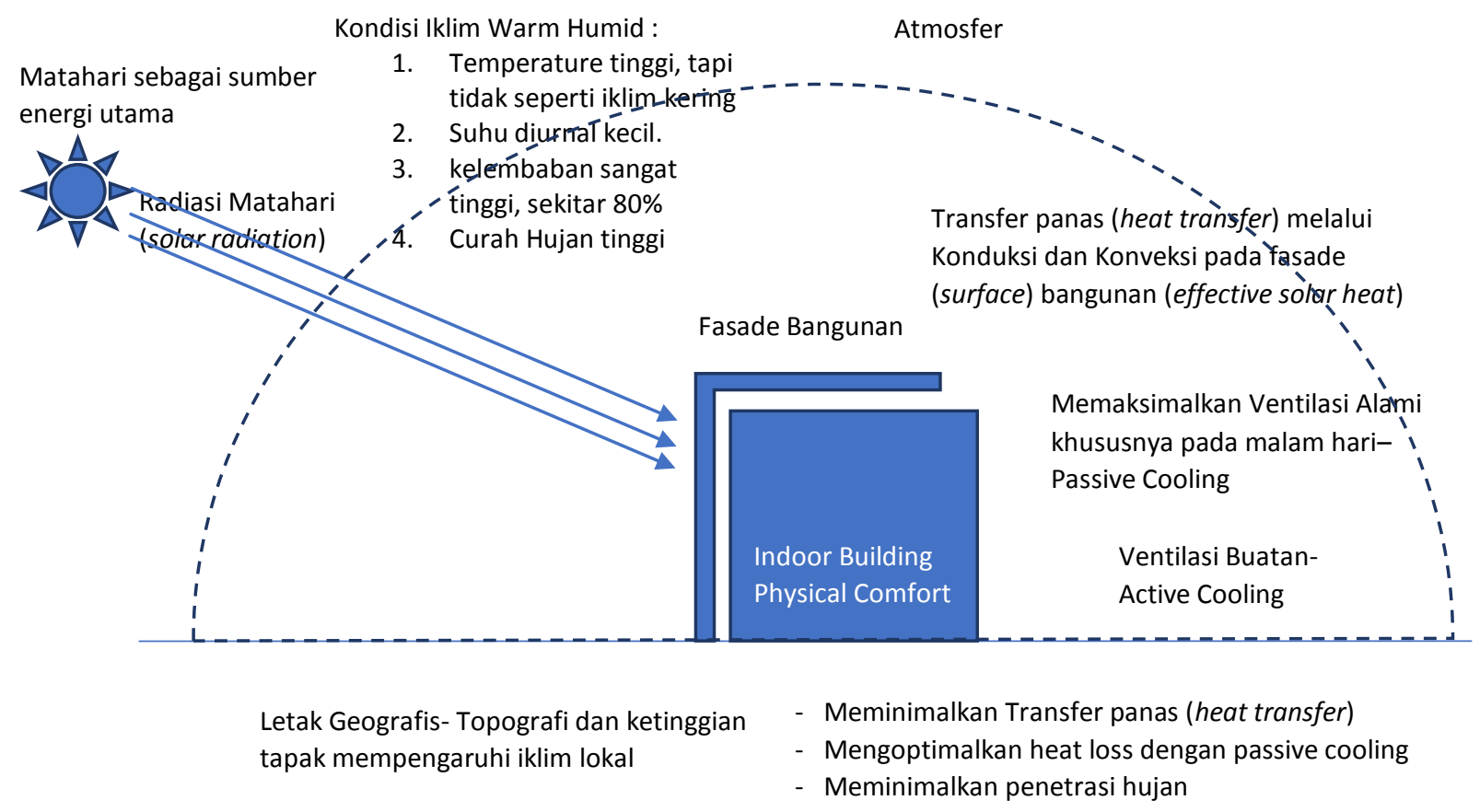

Gambar 2. Prinsip Desain Arsitektur Bioklimatik pada Warm-Humid Climate Region Sumber : Disarikan dari Aronin, 1953; Yeang, 1994; Givoni, 1998; Lippsmeier, 1980; Olgyay, 1963; Evan, 1980; Looman, 2017.

Menyediakan ruang untuk kegiatan semi outdoor sebagai bagian integral dari ruang tamu (Givoni, 1998; Olgyay, 1963), penggunaan konstruksi ringan dan terbuka, dinding merupakan bagian yang paling tidak diutamakan dibandingkan wilayah suhu lainnya dan segala jenis penyerap panas dihidarkan, selain itu penggunaan peneduhan dan permukaan yang dapat memantulkan cahaya (Lippsmeier ,1980; Olgyay, 1963), bangunan harus teduh struktur yang mendorong gerakan udara pendingin dengan cross ventilasi, perlindungan naungan harus di semua sisi yang terkena sinar matahari, untuk menghindari silau baik di dalam maupun di luar, atap harus kedap air, terisolasi, dan memantulkan sinar matahari dan melindungi dari hujan dan mengurangi langit silau. (Olgyay, 1963; Yeang 1994). Selain itu juga perlu ruang transisional di tengah dan disekeliling bangunan sebagai ruang udara dan atrium, insolator panas yang baik pada kulit bangunan dapat mengurangi pertukaran panas yang terik dengan udara dingin yang berasal dari dalam bangunan, Hubungan terhadap Lansekap, lantai dasar bangunan tropis seharusnya lebih terbuka dan menggunakan ventilasi alami dan pertimbangan orientasi bangunan (Yeang, 1994). Bangunan pada daerah tropika basah (Hot Humid Climate) merespon kondisi iklim dengan prinsip yaitu :

1. Meminimalkan intensitas radiasi matahari yang efektif (effective solar exposure) pada building envelope, penggunaan peneduhan atau sunbreaker atau sunshading.. (Olgyay, 1963; Aronin, 1953; Evan,1980; Yeang, 1994; Lippsmeier, 1980; Givoni,1998; Looman, 2017).

2. Meminimalkan perolehan panas matahari efektif ( effective solar heat gain) bangunan, yaitu dengan meminimalkan heat gain pada building envelope. (Evan,1980; Yeang, 1994). 
3. Meminimalkan tingkat perolehan panas konduktif dan konvektif ( conductive and convective) dari udara sekitar, yaitu dengan meminimalkan heat transfer yang terjadi pada building envelope, diantaranya dengan menghindarkan segala jenis penyerap panas pada dinding. (Yeang, 1994; Lippsmeier, 1980).

4. Mengoptimalkan potensi bangunan memperoleh ventilasi alami (natural ventilation) khususnya pada malam hari dan mengoptimalkan pendinginan pasif bangunan (passive cooling) pada bangunan untuk meningkatkan pembuangan panas (heat loss) pada bangunan. (Givoni, 1998; Lippsmeier, 1980; Olgyay, 1963; Evan, 1980).

5. Pemakaian dinding ringan dan tipis karena berguna utama untuk melindungi bangunan dari curah hujan dan meminimalkan risiko badai tropis (tropical storm) (Olgyay, 1963; Aronin, 1953; Givoni, 1998; Lippsmeier, 1980)

6. Melindungi bangunan dari serangga pada bagian dinding bangunan. (Olgyay, 1963; Givoni, 1998)

7. Menyediakan ruang semi outdoor sebagai ruang penyangga antara indoor dan outdoor. (Givoni, 1998)

\section{Prinsip Desain Bioklimatik Pada Daerah Tropika Kering ( Hot Arid Climate Region )}

Prinsip desain bioklimatik pada Hot Arid Climate Region terdiri dari prinsip desain pada musim panas (summer) dan musim dingin (winter). Pada region ini memiliki 4 (empat) musim. Kondisi iklim pada daerah ini memiliki temperature dan radiasi matahari tinggi, dengan variasi suhu diurnal tinggi dan kelembaban relatif sangat rendah (Lippsmeier, 1980). Merespon musim panas (summer) dengan Resist Heat Gain (menurunkan perolehan panas) dan Promote Heat Loss (mengotimalkan pengeluaran panas). Sedangkan merespon musim dingin (winter) dengan Promote Heat Gain (mengoptimalkan perolehan panas) dan Resist Heat Loss (meminimalkan pengeluaran panas) (Watson, 1983).

Bangunan pada daerah tropika kering (Hot Arid Climate) merespon kondisi iklim pada musim panas ( Summer) dengan prinsip yaitu:

(1) Resist Heat Gain (menurunkan perolehan panas) yaitu dengan:

a. Minimize Infiltration, yaitu dengan meminimalkan infiltrasi radiasi matahari yang efektif (effective solar exposure) pada building envelope (Givoni, 1998; Evan, 1980; Aronin, 1953; Watson, 1983) dan juga meminimalkan pengaruh tingginya temperatur luar ruangan (Evan,1980).

b. Minimize Solar Gain, yaitu dengan meminimalkan perolehan panas matahari efektif (effective solar heat gain) bangunan, yaitu dengan meminimalkan heat gain pada building envelope (Watson, 1983; Givoni, 1998).

c. Minimize Conductive Heatflow, yaitu dengan meminimalkan tingkat perolehan panas konduktif dan konvektif (conductive and convective) dari udara sekitar, yaitu dengan meminimalkan temperature udara dalam ruangan (Watson, 1983; Givoni, 1998).

(2) Promote Heat Loss (menaikkan pembuangan panas) yaitu dengan mengoptimalkan potensi bangunan memperoleh ventilasi alami dapat dilakukan dengan :

a. Promote Earth Cooling, mengoptimalkan pendinginan dengan memanfaatkan ruang bawah tanah sebagai buffer zone dan insulation zone antara ruang dalam dan ruang luar. Diantaranya dengan menggukan desain basement atau semi-basement pada bangunan. (Watson, 1983; Looman, 2017)

b. Promote Ventilation, mengoptimalkan pergerakan angin dengan ventilasi alami pada interior bangunan dengan mengopimalkan bukaan, sehingga menciptakan kenyamanan pengguna bangunan. Diantaranya dapat dengan dinding louvered wall (Olgyay, 1963; Watson, 1983; Givoni, 1998; Looman, 2017). 
c. Promote Radiant Cooling, mengoptimalkan pendinginan dengan pemilihan material dinding bangunan (thermal mass) berat dan tertutup (Watson, 1983; Lippsmeier, 1980).

d. Promote Evaporative Cooling, mengoptimalkan pendinginan dengan proses pendinginan penguapan langsung air ke udara dari luar ruangan kedalam ruangan. Prinsip ini dapat dilakukan diantaranya dengan menyemprotkan air ke permukaan atap atau dinding bangunan (Olgyay, 1963; Watson, 1983; Looman, 2017).

Bangunan pada daerah tropika kering (Hot Arid Climate) merespon kondisi iklim pada musim dingin ( Winter) dengan prinsip yaitu:

(1) Promote Heat Gain /Promote Solar Gain

Memaksimalkan tingkat perolehan panas konduktif dan konvektif (conductive and convective) dari udara sekitar, yaitu dengan memaksimalkan tingkat refleksifitas ground cover dan juga permukaan bangunan (building surface) diluar bukaan jendela supaya memaksimalkan perolehan panas pada musim dingin. Juga dengan memaksimalkan pengunaan kaca pada bukaan, penggunaan skylight pada atap bangunan. (Olgyay, 1963; Watson, 1983)

(2) Resist Heat Loss yaitu dengan meminimalkan potensi bangunan memperoleh ventilasi alami dengan:

a. Minimize Conductive Heat Flow, meminimalkan terjadinya aliran konduksi panas pada bagian fasade bangunan (building envelope), diantaranya dapat dengan mendesain attic space sebagai ruang antara interior dan eksterior bangunan (Thermal buffering) (Olgyay, 1963; Watson, 1983; Looman, 2017).

b. Minimize External Air Flow, meminimalkan aliran udara diluar bangunan, diantaranya dapat dengan mendesain landscape dan vegetasi disekitar bangunan berfungsi sebagai windbreak (Watson, 1983).

c. Minimize Infiltration, dengan meminimalkan infiltasi panas pada bukaan bangunan baik jendela maupun pintu (Watson, 1983).

\section{Kesimpulan}

Dari kajian mengenai Arsitektur Bioklimatik dan kondisi iklim di daerah Tropis diatas dapat dirangkum hasil pembahasan mengenai Prinsip Desain Arsitektur Bioklimatik pada Iklim Tropis sebagai berikut :

1. Daerah Tropis merujuk pada terminologi pembagian geografis wilayah di bumi, yaitu merujuk pada daerah diantara garis Tropic of Cancer di $23^{\circ} 27^{\prime}$ LU dan Tropic of Capricorn di $23^{\circ} 27^{\prime}$ LS. Daerah tropis merupakan daerah-daerah yang memperoleh radiasi matahari tegak lurus, dimana diluar daerah tropis tidak mendapatkan radiasi matahari tegal lurus.

2. Iklim Tropis atau kondisi iklim pada daerah tropis terbagi menjadi 2(dua) tipe iklim utama yaitu iklim Tropika Basah ( Hot Humid Climate) dan Iklim Topika Kering (Hot Arid Climate), yang keduanya memiliki karakteristik kondisi iklim yang berbeda.

3. Prinsip Desain Arsitektur Bioklimatik pada Iklim Tropis terdiri dari 2 (dua) tipe meliputi Prinsip desain untuk bangunan pada daerah Iklim Tropika Basah (Hot humid Climate) dan Prinsip desain untuk bangunan pada daerah iklim Tropika kering (Hot Arid Climate ). Hal ini menyesuaikan kondisi iklim dimana bangunan tersebut didesain.

4. Pada daerah Iklim Tropika Basah (Hot humid Climate) mengalami 2 (dua) musim yaitu musim kemarau dan musim penghujan. Beberapa prinsip utama desain Bioklimatik bangunan dalam merespon kondisi iklim daerah ini adalah: (1) meminimalkan intensitas radiasi matahari yang efektif (effective solar exposure) pada building envelope sesuai dengan kemiringan sudut datang sinar matahari pada bangunan, (2) meminimalkan heat gain pada building envelope, (3) meminimalkan tingkat perolehan panas konduktif dan konvektif (conductive and convective) dari udara sekitar, yaitu dengan meminimalkan heat transfer yang terjadi pada building envelope, diantaranya dengan pemilihan material building envelope, (4) mengoptimalkan 
potensi bangunan memperoleh ventilasi alami khususnya pada malam hari dan mengoptimalkan pendinginan pasif bangunan (passive cooling) pada bangunan untuk meningkatkan pembuangan panas (heat loss) pada bangunan, (5) pemakaian dinding ringan dan tipis karena berguna utama untuk melindungi bangunan dari curah hujan dan meminimalkan risiko badai tropis, (6) melindungi bangunan dari serangga pada bagian dinding bangunan, (7) menyediakan ruang semi outdoor sebagai ruang penyangga antara indoor dan outdoor.

5. Pada daerah iklim Tropika kering ( Hot Arid Climate) mengalami 4 (empat) musim sepanjang tahun. Kondisi karakter iklim ekstrem terjadi pada musim panas dan musim dingin yang memerlukan respon pada desain bangunan pada daerah ini. Bangunan merespon musim panas (summer) dengan prinsip utama desain: (1) Resist Heat Gain (menurunkan perolehan panas) dan (2) Promote Heat Loss (mengotimalkan pengeluaran panas). Sedangkan bangunan merespon musim dingin (winter) dengan Promote Heat Gain (mengoptimalkan perolehan panas) dan Resist Heat Loss (meminimalkan pengeluaran panas).

Dari uraian diatas dapat disimpulkan bahwa Prinsip Desain Arsitektur Bioklimatik pada Iklim Tropis terdiri dari 2 (dua) tipe meliputi Prinsip desain untuk bangunan pada daerah Iklim Tropika Basah (Hot humid Climate) yang memiliki 2 musim dan Prinsip desain untuk bangunan pada daerah iklim Tropika kering (Hot Arid Climate) dengan 4 musim. Kedua prinsip desain ini dipengaruhi beberapa perbedaan kondisi iklim diantara kedua wilayah iklim ini. Kedua wilayah ini secara umum memiliki temperatur udara tinggi, perbedaannya adalah perbedaan suhu diurnal diantara kedua wilayah iklim tersebut. Kondisi ini memerlukan respon yang berbeda khususnya pada desain selubung bangunan, dimana desain selubung bangunan mempengaruhi tingkat heat gain (perolehan panas) dan heat loss (pembuangan panas) bangunan tersebut dalam upaya menciptakan indoor thermal comfort pada bangunan.

\section{Daftar Pustaka}

Almusaed, A., (2011), Biophilic and Bioclimatic Architecture, Springer-Verlag London Limited 2011.

Aronin, Jefrey Ellis (1953), Climate and Architecture, Reinhold Publishing Company, New York.

Evans, Martin, (1980), Housing, Climate and Comfort, John Wiley\& Sons, Inc, New York.

Fountain M., Brager Gail, de Dear R. (1996), Expectation Of Indoor Climate Control, Energy and Buildings. Vol. 24. Issue 3, 1 Oktober 1996, P. 179-182.

Givoni, B, (1998), Climate Consideration in Building and Urban Design, John Wiley \&Sons, Inc, Canada.

Hyde, Richard, (2000), Climate Responsive Design : A Study of Building in Moderate and Hot Humid Climate, St Edmundsbury Press, Bury St Edmunds, Suffolk, Great Britain.

Hyde, Richard, ( Editor) (2008), Bioclimatic Housing : Innovative Design for Warm Climates, Cromwell Press, Trowbridge, United Kingdom.

Hastings, R. S., (1989) Computer Design Tools for Climate-Responsive Architecture in Solar and Wind Technology, Vol. 6. Issue 4, P.357-363.

Karyono, (1996), Arsitektur, Ilmu Pengetahuan dan Energi, Konstruksi , Mei hal22.

Karyono, (1989), Solar Energi and Architecture: A Study of Passive Solar Design for Hospital
Wards in Indonesia, MA Dissertation, School of Advanced Architectural Studies, University of York, UK.

Karyono, T.H., (2006), Antisipasi Arsitek dalam Memodifikasi Iklim Melalui Karya Arsitektur, Jurnal Sains dan Teknologi EMAS- Elektro Mesin Arsitektur Sipil, Vol.16, No.3, Agustus, Fakultas Teknik, Universitas Kristen Indonesia.

Koenigsberger, Ingersoll, Mayhew, Szokolay (1973) Manual of Tropical Housing and Building, Commonwealth Printing Press Ltd.

Krishan, A., Baker, N., Yannas, S., Szokolay, S.V., (2001), Climate Responsive Architecture: Design Handbook for Energi Efficient Buildings, Tata McGraw- Hill Publishing Company Limited, New Delhi.

Kukreja, C.P., (1978), Tropical Architecture, Tata McGraw-Hill Publishing Company Limited, New Delhi.

Looman, R. (2017), Climate- Responsive design : A Framework for an energi concept designdecision support tool for architects using principles of climate-responsive design $A+B E /$ Architecture and the Built Environment: DOI: 10.7480/abe.2017.1

Lippsmeier, G., (1980), Bangunan Tropis, Penerbit Erlangga, Jakarta. 
Mangunwijaya, Y. B., (2000), Pengantar Fisika Bangunan, Djambatan, Jakarta.

Mahdavi K. (1996), Implications Of Indoor Climate Control For Comfort, Energy and Environment In Energy And Buildings, Vol.24. Issue 3, 1 Oktober 1996, Amsterdam: Elsevier Science Ltd, P. 167-177.

Oliver, P. (editor) (1997), Encyclopedia of Vernacular Architecture of The World. Vol 1, United Kingdom, Cambridge University Press.

Olgyay, V. (1963), Design with Climate : Bioclimatic Approach to Architectural Regionalism. Princeton : Pronceton University Press.

Prianto E., Suyono, B., Septana, B.P., Indraswara, M.S.,(2018), Resilient Desain Tropis pada Bangunan Kampus Universitas Diponegoro Semarang, Jurnal Modul Vol 18 No. 1, issues period 2018, ISSN (P) 0853-2877 (E) 2598327X,

http://ejurnal.undip.ac.id/index.php/modul.
Szokolay, S.V, (1980), Environmental Science Handbook for Architects and Engineers, New York, John Willey \& Sons.

Szokolay, S. V., (2004), Introduction to Architectural Sciences: The Basis of Sustainable Design, Architectural Press, UK.

Tumimomor, I.A.G., Poli, H., Arsitektur Bioklimatik, Media Matrasain Vol.8 No. 1 Mei 2011.

Watson, Donald, (1983), Climatic Design: EnergyEfficient Building Principles and Practices, Mc Graw Hill, Inc. United States of America.

Widera, B., (2014), Bioclimatic Architecture as an Opportunity for Developing Countries, 30th Internasional Plea Conference, 16-18 December 2014, CEPT University, Ahmedabad.

Yeang, K., (1994), Bioclimatic Skyscrapers, London, Artemis.

Yeang, K., (1996), The Skyscraer Bioclimatically Considered, London, Academy, 1996.

Yeang, K., (1999), The Green Skyscrapers : The Basis for Designing Sustainable Intensive Buildings, Prestel, Munich. 